Research Article

\title{
A comparative study of effect on reducing pain, inflammation and side effect of combination of enzymes (bacterial proteases, papain, bromelain, vitamin $C$ and rutin) versus conventional non-steroidal anti-inflammatory drugs (diclofenac) in patients of closed fracture lower end radius coming at orthopaedic department of a tertiary care hospital
}

\author{
Tejas A. Acharya ${ }^{1}{ }^{*}$, Madhav D. Trivedi $^{1}$, Dimple S. Mehta ${ }^{1}$, \\ Sunita B. Chhaiya ${ }^{1}$, Shreyas P. Gandhi ${ }^{2}$
}

${ }^{1}$ Department of Pharmacology, ${ }^{2}$ Department Orthopaedic, C.U. Shah Medical College, Surendranagar, Gujarat, India

Received: 01 April 2016

Accepted: 07 May 2016

*Correspondence to: Dr. Tejas A. Acharya, Email: drtejasacharya @gmail.com

Copyright: (C) the author(s), publisher and licensee Medip Academy. This is an openaccess article distributed under the terms of the Creative Commons Attribution NonCommercial License, which permits unrestricted noncommercial use, distribution, and reproduction in any medium, provided the original work is properly cited.

\begin{abstract}
Background: Diclofenac and oral systemic enzymes both are commonly used for control of pain and inflammation in fracture lower end radius as well as other such conditions. Some studies have shown that combination of enzymes like bacterial proteases, papain, bromelain, vitamin $\mathrm{C}$ and rutin can reduce pain and Inflammation which is comparable to diclofenac but it still not definite.

Methods: Total 50 patients with closed fracture lower end radius were enrolled and randomly divided in to two groups. Group-1 with 25 patients received oral diclofenac and group-2 with 25 patients received oral preparation which contains combination of enzymes bacterial proteases, papain, bromelain, vittamin $\mathrm{C}$ and rutin. Effect of drug was assessed by improvement in wrist function which was evaluated by patient rated wrist evolution (PRWE) and reduction in oedema on day 1 , day 3 and day 5 . Both the groups were compared by unpaired $\mathrm{Z}$ test.

Results: Mean reduction in PRWE score was 132.08 \pm 5.01 in Group 1 and $104.4 \pm 11.78$ in group 2. Mean of percentage reduction of oedema for group 1 was 8.22 while for group 2 it was 17.8 . Both were statistically significant $(\mathrm{p}<0.05)$. Total 5 patients out of 25 complained of gastritis in group 1 patients while there was no side effect reported in group 2 patients.

Conclusions: Diclofenac was better in reducing pain, while combination of enzymes used in the study was better in reducing oedema. Combination of the enzymes used in this study is safer than diclofenac in cases of the closed fracture lower end radius.
\end{abstract}

Keywords: Pain, Inflammation, Diclofenac, Oral enzymes, Bromelain

\section{INTRODUCTION}

Closed fracture of lower end radius is one of the most common fractures seen in orthopaedic department. ${ }^{1}$ Most common symptoms of patients suffering from closed fracture of lower end radius are pain, tenderness and swelling. $^{2}$
Diclofenac is one of the most commonly used drugs which is from NSAID group and has side effect of gastritis, renal damage. ${ }^{3}$ Oral systemic enzymes play an important role by helping to maintain normal inflammatory processes within the body and thereby supporting speedy healing with minimal or no side effects. ${ }^{4}$ The initial myth that enzymes are not absorbed by gut has been refuted by numerous animal and human 
studies. ${ }^{5}$ Enzymes often bind and act on target with greater affinity and specificity and convert multiple target molecules to the desired products so they can accomplish therapeutic biochemistry in the body that small molecules cannot. $^{6}$

Oral enzymes used in this study are bacterial proteases, papain, bromelain, vitamin $\mathrm{C}$ and rutin in one combination. Bacterial proteases, papain and rutin have important role in treatment of various types of inflammations. ${ }^{7,8}$ Bromelain is a natural proteinase preparation derived from pineapple stem that is marketed for oral use as a digestive aid and as an anti-inflammatory agent. ${ }^{9}$ Studies have also shown presence of this enzyme in the plasma. ${ }^{10,11}$ Bromelain also contains chemicals that interfere with the growth of tumor cells and slow blood clotting. $^{12}$ It also appears to have the advantage of selectively controlling some of the biochemical causes of pain and inflammation rather than the often-uncontrolled effect of NSAIDS. ${ }^{13-15}$ It has shown effective role in reducing inflammation in animal studies. ${ }^{16-18}$ Some human studies have showed that treatment with bromelain in various inflammatory conditions including blunt and musculoskeletal injuries can provide efficacy comparable to NSAIDs. ${ }^{19-23}$

So, this study was carried out with aims of comparing effect of Diclofenac and different proteolytic enzymes (combination of bacterial proteases, papain, bromelain, vitamin $\mathrm{c}$ and rutin) in reducing the pain and inflammation in patients suffering from close fracture of lower end radius and monitoring of side effects in both the drug groups.

\section{METHODS}

This study was carried out after written permission from institution ethical committee. The study involved 50 adult patients of either gender with closed fracture lower end radius coming at orthopaedic department of our hospital.

Following patients were excluded from the study: 1) Patients with hereditary or acquired clotting disorder. 2) Patients allergic to protein. 3) Patients with liver dysfunction and patients undergoing dialysis. 4) Patients with pregnancy and lactation. Diagnosis as well as treatment of closed fracture of lower end radius was done by orthopaedic surgeon on the basis of X-ray film. Informed consent was taken from the patients. Total 50 numbers of patients were divided in to two groups randomly having 25 Patients in each group wiz; (I) group 1 receiving oral diclofenac. (II) group 2 receiving oral preparation which contains combination of enzymes bacterial proteases, papain, bromelain, vitamin $\mathrm{C}$ and rutin.

Before starting the treatment following parameters were measured as baseline parameters: 1) Assessments of wrist function by "patient rated wrist evolution" (PRWE) score out of 150.2) measurement of size of oedema by measure tape (in $\mathrm{cm}$ ). The aim of the PRWE questionnaire is to provide a reliable and valid tool for quantifying patientrated wrist pain and disability in order to assess outcome in patients with distal radius fractures. ${ }^{24}$ PRWE score provides a brief, reliable and valid measure of patient rated pain and disability. ${ }^{25}$ Group 1 was treated with tablet containing diclofenac $50 \mathrm{mg}$ bid, group 2 was treated with tablet containing (bacterial proteases $25 \mathrm{mg}$, papain $100 \mathrm{mg}$, bromelain $175 \mathrm{mg}$, vitamin C $20 \mathrm{mg}$, rutin $50 \mathrm{mg}$ ) bid. On follow up after $3^{\text {rd }}$ and $5^{\text {th }}$ days of treatment above parameters were repeated. Patients were asked for side effects if any. Results were compared between the two groups on the basis of findings of day 1 and day 5. Mean reduction of PRWE score was calculated by subtracting mean score of day 1 from score of day 5. Percentage change of oedema was calculated by.

$$
\begin{gathered}
\text { Mean oedema } \\
\begin{array}{c}
\text { before treatment-Mean oedema } \\
\text { after treatment }
\end{array} \\
\text { Mean oedema before treatment }
\end{gathered} \times 100
$$

Comparison of both parameters was done by statistical analysis. Mean reduction in PRWE score and mean change in percentage oedema in both the groups were compared by using unpaired $\mathrm{Z}$ test.

\section{RESULTS}

Total 50 patients completed the study. Out of 50 patients 25 were included in group 1 for diclofenac therapy, while 25 patients were included in group 2 for enzyme combination treatment.

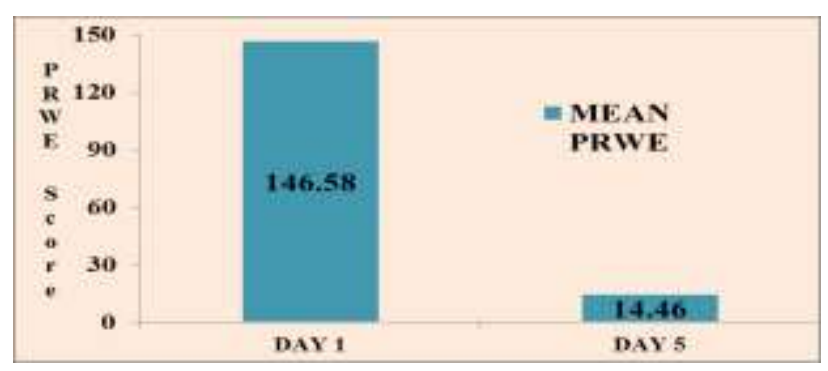

Figure 1: Mean PRWE score in group 1 patients.

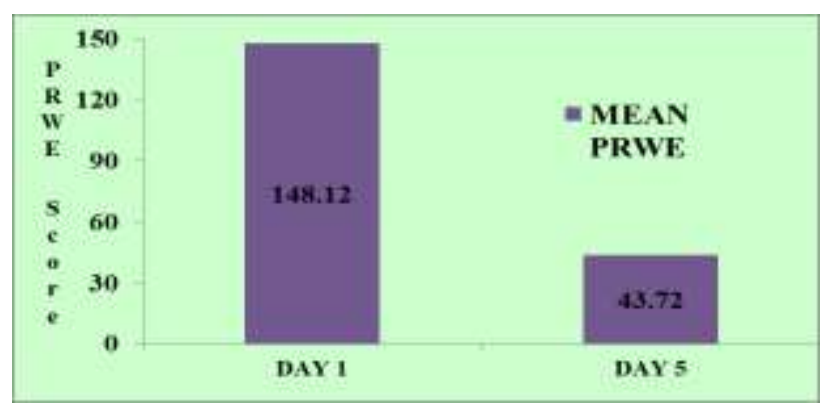

Figure 2: Mean PRWE score in group 2 patients. 
In group 1 total 25 patients received treatment out of which 13 were male and 12 were female. Mean PRWE score in group 1 on day 1 was $146.58 \pm 0.50$, which reduced to $14.46 \pm 4.97$ on day 5 (Figure 1). In group 2 total 25 patients received treatment out of which 14 were male and 11 were female. Mean PRWE score in group 2 on day 1 was $148.12 \pm 4.92$, which reduced to $43.72 \pm 11.35$ on day 5. (Figure 2) From the above obtained results mean reduction in PRWE score was calculated. Mean reduction in PRWE score was 132.08 \pm 5.01 in group 1 and $104.4 \pm 11.78$ in group 2. (Figure 3 ) On comparison it is evident that mean reduction in PRWE score is more in group 1 as compared to group 2. This association was found to be statistically significant $(Z=16.72)(p<0.05)$. It reveals that Diclofenac is more effective in reducing pain as compared to combination of enzymes used in this study.

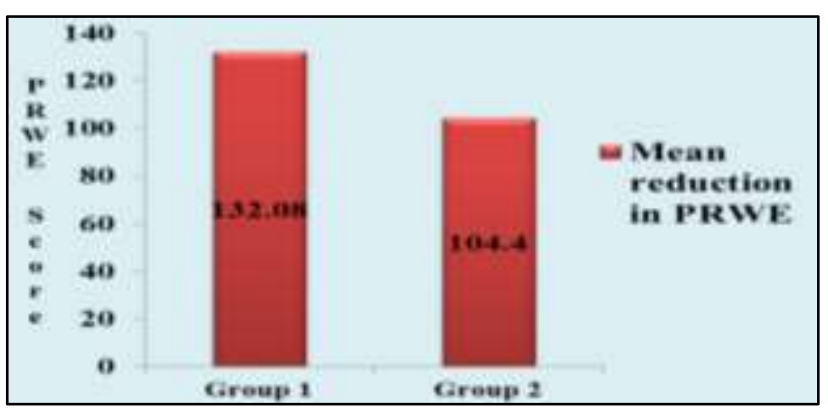

Figure 3: Comparision of mean reduction of PRWE score in group 1 and 2 patients.

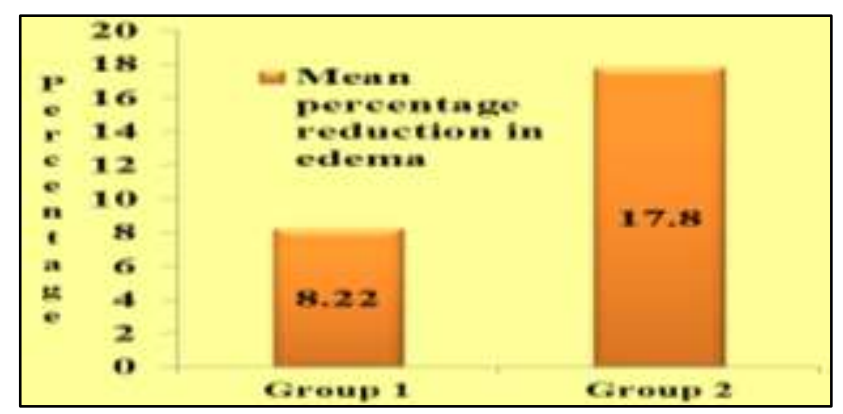

Figure 4: Comparison of MPRE in group 1 and 2 patients.

Mean size of oedema in group 1 was $6.57 \pm 0.35$ on day 1 , which reduced to $6.03 \pm 0.41$ on day 5 . So on application of formula mentioned in methods, mean percentage reduction of oedema in group is 8.22 . For group 2 mean size of oedema was $6.63 \pm 0.48$ on day 1 , which reduced to $5.45 \pm 0.58$ on day 5 . It reveals that mean percentage reduction of oedema in group 2 is 17.8. (Figure 4) From the above results it is evident that mean percentage reduction of oedema is more in group 2 as compared to group 1. On application of statistical parameter it revealed that association was statistically significant $(Z=10.88)$ $(\mathrm{p}<0.05)$. It indicates that combination of enzymes used in this study is more effective in reducing oedema as compared to diclofenac.
To summarise all the parameters, mean reduction of PRWE score is more in group 1, while mean percentage reduction in oedema is more in group 2. (Table 1) Total 5 patients out of 25 complained of Gastritis in group 1 patients while there was no side effect reported in group 2 patients.

Table 1: Overall comparision of PRWE score and mean percentage reduction of oedema in group 1 and group 2 patients.

\begin{tabular}{|llll|l|}
\hline Group & $\begin{array}{l}\text { PRWE } \\
\text { on } \\
\text { Day 1 }\end{array}$ & $\begin{array}{l}\text { PRWE } \\
\text { on } \\
\text { Day 5 }\end{array}$ & $\begin{array}{l}\text { Mean } \\
\text { reduction } \\
\text { in PRWE }\end{array}$ & $\begin{array}{l}\text { Mean } \\
\text { Percentage } \\
\text { reduction } \\
\text { in oedema }\end{array}$ \\
\hline Group 1 & 146.58 & 14.46 & 132.08 & 8.22 \\
\hline Group 2 & 148.12 & 43.72 & 104.4 & 17.8 \\
\hline
\end{tabular}

\section{DISCUSSION}

This study was carried out with an approach to compare oral enzymes with conventional NSAID in order to study role of oral enzymes in inflammatory conditions like fracture lower end of radius. The results of the present study revealed that diclofenac was more effective as compared to enzymes combination in reduction of mean PRWE score at the end of treatment while enzymes combinations significantly reduced oedema as compared to diclofenac.

A study involving 59 patients with blunt injuries to the musculoskeletal system found that treatment with bromelain resulted in a clear reduction in all four parameters tested; swelling, pain at rest and during movement, and tenderness with good tolerability. ${ }^{19}$ Another study with the enzyme combination containing bromelain in ankle sprain has shown good efficacy in reducing swelling when compared to placebo, but not superior to two or three drug combinations. ${ }^{26}$ These results are comparable to our study; however our study has included comparison with diclofenac, which showed superiority over enzyme combination in reduction of pain.

Another study conducted by Klein and Kullich's in patients of osteoarthritis reported equivalent reduction in pain indices of $80 \%$ for the two treatments during 3 weeks of therapy and 4 weeks of follow-up with few adverse reactions to either treatment. ${ }^{12}$ Difference may be due to selected disease condition which is chronic in nature as compared to present study which is on acute inflammatory condition.

One another study on similar acute inflammatory condition was reported by Kamenicek V who compared systemic enzyme combination with standard anti oedematic drugs for the treatment and prevention of posttraumatic and postoperative swelling. ${ }^{27}$ They clearly demonstrated that simple administration per OS, efficient oedema reduction and thus accelerated healing and analgesic effect all these advantages justify the 
application of this therapeutic method what can be recommended as a part of the complex treatment in traumatology with both conservative and surgical approaches. Our study failed to demonstrate advantage of enzyme combination in pain reduction as compared to diclofenac which may be due to either lack of efficacy or unsuitable clinical model.

Considering results of safety analysis tolerability of enzyme combination can be rated as good. Reduction in swelling was clear advantage of enzyme combination, however as compared to diclofenac, failure in demonstrating efficacy in reduction of pain, cannot provide solution of alternative treatment in conditions like fracture lower end radius. One major limitation of this study was small sample size. Reduction of pain and swelling was assessed by clinical methods instead of biochemical parameters, which can also be the reason of bias in results of present study. Further studies are warranted to compare effects of combination of enzymes with diclofenac in fracture lower end radius.

\section{CONCLUSION}

From the result and discussion we conclude that Diclofenac is better in reducing pain as compared to combination of enzymes (bacterial proteases, papain, bromelain, vitamin $\mathrm{C}$ and rutin) while combinations of enzymes reduce oedema better than diclofenac. Combination of the enzymes used in this study is safer than diclofenac in cases of the fracture lower end radius.

\section{ACKNOWLEDGEMENT}

The authors are thankful to former Dean Dr. H. H. Agravat Sir, for allowing us to carry out this research project in our hospital. The authors also thankful to Dr. Hitesh Solanki and Dr. Biren Patel (Former Residents in Dept. of Orthopaedics), Dr. Saket Thaker, Dr. Vidisha Shah (Former residents in department of pharmacology) and whole pharmacology department for their help to accomplish this study.

Funding: No funding sources Conflict of interest: None declared

Ethical approval: The study was approved by the Institutional Ethics Committee (CUSMC/IEC(H)/Approval-26/3893/6/2010

\section{REFERENCES}

1. Nellans KW, Kowalski E, Chung KC. The epidemiology of distal radius fractures. Hand Clinics. 2012;28(2):113-25.

2. American academy of orthopaedic surgeons. Distal radius fractures (broken wrist). Orthoinfo org. Available at http://orthoinfo.aaos.org/PDFs/A00412.pdf

3. Tripathi KD. Nonsteroidal anti-inflammatory drugs and antipyretics- analgesics. In: Essentials of medical
Pharmacology. $6^{\text {th }}$ ed. New Delhi: Jaypee Brothers Medical Publishers Ltd; 2008:184-201.

4. Mazourov VI, Lila AM, Klimko NN. The efficacy of systemic enzyme therapy in the treatment of rheumatoid arthritis. Int $\mathrm{J}$ immunotherapy. 1997;13:85-91.

5. Shahid S. Role of systemic enzymes in infections. Webmed Central Complementary Medicine. 2011;2(11):WMC002495.

6. The enzyme as drug: Application of enzymes as pharmaceuticals, current opinion in biotechnology. 2003;14:1-7.

7. Rakhimov MR. Anti-inflammatory activity of domestic papain. Eksp Klin Farmakol. 2001;64(4):48-9.

8. Selloum L, Bouriche H, Tigrine C, Boudoukha C. Anti-inflammatory effect of rutin on rat paw oedema, and on neutrophils chemotaxis and degranulation. Exp Toxicol Pathol. 2003;54(4):313-8.

9. Hale LP, Greer PK, Sempowski GD. Bromelain treatment alters leukocyte expression of cell surface molecules involved in cellular adhesion and activation. Clinical Immunology. 2002;104:183-90.

10. Smyth RD, Brennan R, Martin GJ. Studies establishing the absorption of bromelains (proteolytic enzymes) from the gastrointestinal tract. Exp Med Surg. 1964;22:46-59.

11. Castell JV, Friedrich G, Kuhn CS. Intestinal absorption of undegraded proteins in men: presence of bromelain in plasma after oral intake. Am J Physiol. 1997;273:139-46.

12. Klein G, Kullich W. Short-term treatment of painful osteoarthritis of the knee with oral enzymes: a randomised, double-blind study versus Diclofenac. Clin Drug Invest. 2000;19:15-23.

13. Singer F, Singer C, Oberleitner H. Phlyoenzym versus diclofenac in the treatment of activated osteoarthritis of the knee. Int $\mathbf{J}$ Immunother. 2001;17:135-41.

14. Fitzhugh DJ, Shan S, Dewhirst MW, Hale LP. Bromelain treatment decreases neutrophil migration to sites of inflammation. Clinical immunology (Orlando, Fla). 2008;128(1):66-74.

15. Maurer HR. Bromelain: biochemistry, pharmacology and medical use. Cell Mol Life Sci. 2001;58(9):1234-45.

16. Uhlig G, Seifert J. The effect of proteolytic enzymes (traumanase) on posttraumatic oedema. Fortschr Med. 1981;99(15):554-6.

17. Pirotta F, de Giuli-Morghen C. Bromelain: antiinflammatory and serum fibrinolytic activity after oral administration in the rat. Drugs Exp Clin Res. 1978;4:1-20.

18. Izaka K, Yamada M, Kawano T. Gastrointestinal absorption and anti-inflammatory effect of bromelain. Jpn J Pharmacol. 1972;22:519-34.

19. Masson M. Bromelain in blunt injuries of the locomotor system. A study of observed applications in general practice. Fortschr Med. 1995;113:303-6. 
20. Wittenborg A, Bock PR, Hanisch J, Saller R, Schneider B. Comparative epidemiological study in patients with rheumatic diseases illustrated in a example of a treatment with non-steroidal antiinflammatory drugs versus an oral enzyme combination preparation. Arzneimittel-Forschung. 2000;50:728-38.

21. Akhtar NM, Naseer R, Farooqi AZ, Aziz W, Nazir M. Oral enzyme combination versus Diclofenac in the treatment of osteoarthritis of the knee: a doubleblind prospective randomized study. Clin Rheumatol. 2004;23:410-5.

22. Rovenska E, Svik K, Stancikova M, Rovensky J. Inhibitory effect of enzyme therapy and combination therapy with cyclosporin A on collagen-induced arthritis. Clin Exp Rheumatol. 2001;19:303-9.

23. Brien S, Lewith G, Walker A, Hicks SM, Middleton D. Bromelain as a treatment for osteoarthritis: a Review of Clinical Studies. Evidence-based
Complementary and Alternative Medicine. 2004;1(3):251-7.

24. Changulani M, Okonkwo U, Keswani T, Kalairajah Y. Outcome evaluation measures for wrist and hand which one to choose? International Orthopaedics. 2008;32(1):1-6.

25. MacDermid JC, Turgeon T, Richards RS, Beadle M, Roth JH. Patient rating of wrist pain and disability: a reliable and valid measurement tool. J Orthop Trauma. 1998;12:77-86.

26. Kerkhoffs G, Struijs P, de Wit C, Rahlfs V, Zwipp H, van Dijk CN. A double blind, randomised, parallel group study on the efficacy and safety of treating acute lateral ankle sprain with oral hydrolytic enzymes. British Journal of Sports Medicine. 2004;38(4):431-5.

27. Kamenicek V, Halon P, Franek P. Systemic enzyme therapy in the treatment and prevention of posttraumatic and postoperative swelling. Acta Chir Orthop Traumatol Cech. 2001;68(1):45-9.

Cite this article as: Acharya TA, Trivedi MD, Mehta DS, Chhaiya SB, Gandhi SP. A comparative study of effect on reducing pain, inflammation and side effect of combination of enzymes (bacterial proteases, papain, bromelain, vitamin $\mathrm{C}$ and rutin) versus conventional non-steroidal anti-inflammatory drugs (diclofenac) in patients of closed fracture lower end radius coming at orthopaedic department of a tertiary care hospital. Int J Basic Clin Pharmacol 2016;5:1017-21. 